\title{
Economic analysis of dairy cattle farms in east Mediterranean region of Turkey
}

\author{
Hilal Yilmaz¹, Mevlüt Gül2, Selcan Akkoyun'1, Oguz Parlakay³, Mehmet Emin Bilgili', Yasemin \\ Vurarak ${ }^{1}$, Hatice Hizli' ${ }^{1}$, Numan Kilicalp ${ }^{4}$
}

\author{
Eastern Mediterranean Agricultural Research Institute, Adana, Turkey. \\ 2 Süleyman Demirel University, Faculty of Agriculture, Department of Agricultural Economics, Isparta, Turkey. \\ ${ }^{3}$ Mustafa Kemal University, Faculty of Agriculture, Department of Agricultural Economics, Hatay, Turkey. \\ ${ }^{4}$ Gaziosmanpaşa University, Department of Animal Science, Tokat, Turkey.
}

\begin{abstract}
The purpose of this study was to calculate costs of milk production, gross production value, gross margin, absolute profit, and relative profit of dairy cattle farms located in the provinces of east Mediterranean region of Turkey. Primary data were collected from 148 dairy cattle farms designated using the Neyman Stratified Sampling method through surveys. Dairy farms were classified into four groups according to the number of cows. The data belong to the 2012 production season. A single product budget analysis method was used for calculating production costs. According to the results, variable costs amounted to $65.91 \%$ of total production costs. Feed cost $(86.52 \%)$ was the main component of variable costs. The cost of $1 \mathrm{~kg}$ of milk, on average, was calculated as USD 0.261. The cost of milk was USD 0.499 on group 1 farms, USD 0.399 on group 2 farms, USD 0.272 on group 3 farms, and USD 0.233 on group 4 farms. Among the farms under study, average gross margin value was negative only on group $1 \mathrm{farm}$, and positive in all other groups. Absolute profit value was positive only on group 4 farm, and negative in all other groups. The average relative profit of the farms was 0.9067 . The expansion of dairy farms could be reached by reducing the feed cost as well as increasing the scale of farms.
\end{abstract}

Key Words: gross margin, milk production cost, profit, variable cost

\section{Introduction}

The animal husbandry sector plays a significant role in agricultural development of nations not only in terms of the products it produces but also because it generates added value and employment opportunities as much as other sub-sectors of agriculture. The animal husbandry sector maintains its production activities while also steers and promotes the production of inputs like forage plant breeding required for its own production.

The number of different species in Turkey as of 2013 was $55.21 \%$ sheep (29.3 million head), $27.18 \%$ cattle (14.4 million head), and $17.39 \%$ goat (9.2 million head). Of the total cattle, $42.40 \%$ are crossbreeds (6.1 million head), $41.30 \%$ are pure breeds (5.9 million head), and $16.30 \%$ are local breeds (2.3 million head) (TÜIK, 2014).

In the year 2013, total milk production in Turkey was $18,223,712 \mathrm{t}$. A total of $16,655,009 \mathrm{t}$ of this production,

Received October 8, 2015 and accepted May 6, 2016.

Corresponding author: htarim01@gmail.com

http://dx.doi.org/10.1590/S1806-92902016000700008

Copyright (C) 2016 Sociedade Brasileira de Zootecnia. This is an Open Access article distributed under the terms of the Creative Commons Attribution License (http://creativecommons.org/licenses/by/4.0/), which permits unrestricted use, distribution, and reproduction in any medium, provided the original work is properly cited. which is $91.39 \%$, come from cow milk. Of all the animals that can be milked, sheep milk production has a very low rate, although the number of sheep is considerably high (TÜİK, 2014).

In the last thirty three years, world milk production has increased by $65 \%$; Turkey milk production has also increased by $90 \%$. India is the largest milk producer, with $17.6 \%$ of the world production, followed by the United States of America, China, Pakistan, Brazil, Germany, Russian Federation, France, New Zealand, and Turkey. In 2013, 768.6 billion tons of milk were produced in the world. Dairy cattle represented 635.6 billion tons and $82.7 \%$ of the total milk production. The share of cow milk production in total milk production is $91.4 \%$ in Turkey (FAOSTAT, 2016). This proportion has decreased regularly since 1980 for the world, but has increased for Turkey data. Turkey is ranked ninth in the world cow milk production. Cow milk yield per animal, in 2013, was 7,758 kg in the UK, 7,293 kg in Germany, 6,414 kg in France, and 2,970 kg in Turkey (FAO, 2016).

It could be said that dairy cattle and beef cattle are the most important production branches that constitute a sub-sector of animal husbandry. In this concept, beef cattle could be improved depending on dairy cattle. This is mostly because the main material of beef cattle is obtained from 
dairy cattle. In this sense, dairy cattle could be accepted as the primary production branch. Studies supporting dairy cattle also improve beef cattle, which in turn it helps the development of animal husbandry in the county.

There are a number of studies about dairy cattle in Turkey. However, region-based studies are few and limited. In this study, we aimed to designate milk production cost, gross production value, gross margin, absolute profit, and relative profit values on agricultural farms engaged in dairy cattle in the east Mediterranean region (specified as the research field for this study).

\section{Material and Methods}

The results of the study were obtained for TR62 and TR63 Region by Level 2 of The Nomenclature of Territorial Units for Statistics (NUTS) of the Mediterranean region of Turkey (TÜIK, 2014). These provinces are Adana, Mersin, Osmaniye, Hatay, and Kahramanmaraş in the east Mediterranean region of Turkey. The suitability of the climate and geographical location of the region is advantageous from the agricultural aspects. It provides a significant contribution to the economy of the region with crop production livestock. Adana is located between $35^{\circ}$ and $38^{\circ} \mathrm{N}$ latitudes and between $34^{\circ}$ and $36^{\circ} \mathrm{E}$ longitudes. The surface area of Adana province is $14,030 \mathrm{~km}^{2}$ and $38 \%$ of the land area of the Adana province is agriculture land. The agriculture land area of Adana is about $2.0 \%$ of the total agriculture land area of Turkey. Hatay is located between $35^{\circ} 52^{\prime}$ and $37^{\circ} 04^{\prime} \mathrm{N}$ latitudes and between $35^{\circ} 40^{\prime}$ and $36^{\circ} 35^{\prime} \mathrm{E}$ longitudes. Hatay covers approximately $5,827 \mathrm{~km}^{2}$ in land area, which is about $1.0 \%$ of the total agriculture land area of Turkey. Four percent of the land area of the Hatay province is agriculture land. Osmaniye is located between $36^{\circ} 57^{\prime}$ and $37^{\circ} 45^{\prime} \mathrm{N}$ latitudes and between $35^{\circ} 52^{\prime}$ and $36^{\circ} 42^{\prime} \mathrm{E}$ longitudes. Osmaniye covers approximately $3,280 \mathrm{~km}^{2}$ in land area, which is about $0.5 \%$ of the total agriculture land area of Turkey. Approximately $42 \%$ of the provincial land is forest and scrub, $39 \%$ is agriculture land area, $2 \%$ is meadows and pasture, and $17 \%$ is unsuitable for agriculture. Mersin is located between $36^{\circ}$ and $37^{\circ} \mathrm{N}$ latitudes and between $33^{\circ}$ and $35^{\circ} \mathrm{E}$ longitudes. Mersin covers approximately $15,853 \mathrm{~km}^{2}$ in land area, which is about $1.6 \%$ of the total agriculture land area of Turkey. Kahramanmaras is located between $37^{\circ}$ and $38^{\circ} \mathrm{N}$ latitudes and between $36^{\circ}$ and $38^{\circ}$ E longitudes. Kahramanmaraş covers approximately $14,346 \mathrm{~km}^{2}$ in land area, which is about $1.5 \%$ of the total agriculture land area of Turkey.

The Mediterranean region (14,415,257 head) constitutes $8.56 \%$ of the Turkey total cattle number. The research area makes up $60.53 \%$ of cattle number in the Mediterranean region. Milk production in the Mediterranean region accounted for $9.64 \%(16,655,009$ t) of the total milk production in Turkey. The research area covered $56.19 \%$ of the milk production of Mediterriean region. The total milk production in the investigated region is $1,022,011 \mathrm{t}$ and $901,942 \mathrm{t}$ is cow milk, constituting $88.25 \%$ of total milk production (TÜIK, 2014).

The number of cattle was 633,168 head in 1991, declined to 522,800 head in 2000 , and then to 491,878 head in 2005 . After the year 2005, cattle numbers reached 676,707 head with the animal husbandry support and forage crop support in 2015 (TÜIK, 2016).

The total cattle number in the study area is 676,707 head. The number of cattle in the study area has increased by $29 \%$ compared with 2000 . The structure of the cattle farms has also changed. A total of $52.7 \%$ of total cattle number was crossbreeds, $40.6 \%$ was pure breeds, and $6.7 \%$ was local breeds in 2015. But in the year 2000, the percentage of pure breeds was 12.3 , while that of local breeds was 23.8 in the region.

The main material of the research comes from the data obtained from face-to-face interviews and survey with farms engaged in dairy cattle in Adana, Osmaniye, Mersin, Hatay, and Kahramanmaraş provinces of east Mediterranean region.

Total numbers of animals from these five provinces were obtained from the Ministry of Food, Agriculture and Livestock. Using the "purposive sampling method", two towns with the highest number of animals from each province and two villages with the highest number of animals from each province were chosen. The volume of the sample was calculated using the "Neyman Sampling Method/Allocation" which was one of the stratified sampling (Çiçek and Erkan, 1996). For this research, error rate was $5 \%$ and reliability rate was $95 \%$. Farms were divided into four groups. Ten farms constituted group I (1-2 head); 44 farms constituted group II (3-8 head); 75 farms represented group III (9-28 head); and, finally, 19 farms were for group IV (29 and over head dairy cattle), all amounting to 148 farms.

Animal population of the farms in dairy cattle activities was converted to animal units (AU) by means of coefficients (Erkuş et al., 1995).

Economic results could be calculated for all farms or for a branch of production or activity. In the context of this study, gross production value of dairy cattle farm was comprised of value of milk and dairy products produced on the farm, productive stock value (PSV), and manure value (Y1lmaz et al., 2000). Gross production value was 
calculated for milk production branch as well as dairy cattle activities. This is necessary for calculating the cost of milk. Gross production value of milk production branch is comprised of value of milk and dairy products produced on the farm, value of new-born calf, and value of manure (Yurdakul, 1978).

Gross margin in dairy cattle was calculated by subtracting variable costs from gross production value. Absolute profit was also calculated by subtracting production costs from gross production value that the farms obtain from dairy cattle activities. Relative profit was calculated by dividing gross production value by production costs. Production costs in dairy cattle activities are divided into two main groups: fixed costs and variable costs. Variable costs are defined as expenses increasing or decreasing depending on the production value. Fixed costs are defined as expenses which do not change depending on production volume.

In this study, variable costs were feed, veterinary-drugs, salt, electricity, water, insurance, artificial insemination, marketing, maintenance, and fuel costs. Fixed costs were depreciations, interests, labour, building maintenance and repairs, and general management costs.

Production of milk was also calculated in the research. To calculate the cost of milk production, production costs of the milk production branch, which was a production branch of dairy cattle farm, needs to be calculated. Thus, production costs directly related to this branch were separated from production costs for dairy cattle. These direct expenses were mostly feed costs of milk cows. In the survey, feed for milk cows and other cattle were mapped separately. Feed for milk cows, which was a direct cost of milk production branch, was calculated on survey forms. At the same time, there was a separate question about veterinary costs; these costs for milk cows were also obtained from survey forms. Interest on cow capital, cow depreciation, insurance premium, expenses for machines (milking machines), which were only for milk production branch, and artificial insemination expenses, which were directly related to milk production branch, were all calculated separately and only expenses which were directly related to milk production branch were found out. Expenses which do not belong to any production branch in dairy cattle rearing were common expenses of dairy cattle rearing. Milk production branch expenses were calculated considering gross production value share of gross production value of this production branch.

In the context of this study, $1 \mathrm{~kg}$ milk cost was calculated using the Method of Residue, which was one of the joint cost calculation methods.

\section{Results}

On the farms examined in this study, feed costs $(86.52 \%)$ have a vast majority over variable cost average values. It was respectively followed by veterinary-drug costs $(7.67 \%)$, artificial insemination costs $(2.95 \%)$, and electricity cost (1.25\%) (Table 1$)$.

A considerable part of variable costs was comprised of feed costs $(86.52 \%)$ on the farms of this study. A total of $56.88 \%$ of feed costs were concentrated feed and $43.12 \%$ of them were forage. When farm sizes were taken into account, concentrate feed ratio in all feed costs was much more on group 1 and 2 farms, while in group 4 forage cost was relatively more than in the others.

Average variable cost for each animal unit on the farms was USD 1,068.86. Of this value, USD 924.78 was feed costs. Variable costs per each animal unit were highest on group 1 farm and lowest on group 3 farm. Among the average value of variable costs per animal unit, feed costs $(86.52 \%)$ was the highest in group 3 (Table 1$)$. The relationship between farm groups and variable cost elements was statistically significant to a great extent.

Among all average values of fixed costs on farms, labour costs are the highest (61.92\%) (Table 2). Labour cost was ranked 2nd after feed cost when total costs was considered. Labour on the farms was categorised into family labour and permanent non-family worker (on oral/written contract basis for six and more months). On the farms of this study, it was found out that family labour was extensively used and only 17 farms (11.49\%) outsourced the workforce permanently. According to farm averages, family labour fee of all labour cost was $74.94 \%$ and the ratio of outsourcing the workforce permanently was $25.06 \%$. When farm groups were checked, there was no ratio of outsourcing the workforce permanently in labour costs for group 1 farm; however, the ratio was $59.80 \%$ for group 4 . It could be concluded here that family labour was significant for farms; however, as farms get bigger, outsourcing the workforce permanently increases. In the fixed costs, labour costs were followed by depreciation cost (16.44\%), interest costs (15.85\%), and general management costs $(5.79 \%)$, respectively (Table 2$)$.

Average fixed cost per animal unit on farms was USD 552.66, labour costs constituting USD 342.21 of it. Labour costs per animal unit were the highest on group 1 farm and the lowest in group 4 . The highest ratio of all fixed costs per animal unit was labour costs, which were $61.92 \%$ (Table 2).

It was found out that there was a $1 \%$ significant difference between farm groups and interest costs, labour costs, general management costs, and total fixed costs. 
For the average of all farms examined, production cost per animal unit was USD 1,621.52. About $65.91 \%$ of this value was variable costs and $34.09 \%$ of it was fixed costs. When farms groups were considered, production costs per animal unit were the highest on group 1 farm and the lowest on group 3 farm (Table 3 ).

Gross production value (GPV) for the farms which were examined was USD 35,196.82. Milk production value constitutes a greater part of GPV (USD 22,918.95) in the dairy cattle branch. Gross production value was the lowest on group 1 farm (USD 2,363.90) and the highest (USD
154,507.41) on group 4 farm. Gross production value per animal unit was USD 1,401.32 on the average of farms; it was the lowest on group 3 farm and the highest on group 4 farms (Table 3).

Milk production value constitutes $65.12 \%$ of GPV, which was calculated for dairy cattle farms of this study. It was respectively followed by productive stock value $(30.38 \%)$, manure value $(3.30 \%)$, and dairy products value $(1.20 \%)$ (Table 3$)$.

To measure the success of the farm activities, gross margin is used in enterprise analysis. Gross margin can

Table 1 - Variable costs per animal unit according to farm group (USD) and distribution (\%)

\begin{tabular}{|c|c|c|c|c|c|}
\hline \multirow{2}{*}{ Variable costs element } & \multicolumn{4}{|c|}{ Farm group } & \multirow{2}{*}{ Average } \\
\hline & I & II & III & IV & \\
\hline \multicolumn{6}{|c|}{ Value (USD/animal unit) } \\
\hline Feed & 1184.47 & 1049.52 & 807.28 & 963.06 & 924.78 \\
\hline Veterinary and drugs & 111.65 & 105.50 & 67.10 & 71.02 & 82.03 \\
\hline Salt & 1.61 & 5.33 & 1.49 & 0.93 & 2.57 \\
\hline Electricity & 23.17 & 14.82 & 11.19 & 13.45 & 13.37 \\
\hline Water & 6.49 & 9.02 & 6.23 & 4.76 & 6.89 \\
\hline Insurance & - & - & 2.90 & 5.69 & 2.20 \\
\hline Artificial insemination & 63.64 & 30.95 & 28.43 & 27.86 & 31.49 \\
\hline Marketing & - & 1.86 & - & - & 0.55 \\
\hline Machine maintenance and repairs & - & 0.86 & 4.77 & 4.00 & 3.19 \\
\hline Fuel & - & 1.39 & 2.64 & 0.29 & 1.79 \\
\hline Total & 1391.03 & 1219.23 & 932.05 & 1091.06 & 1068.86 \\
\hline \multicolumn{6}{|c|}{$\%$} \\
\hline Feed & 85.15 & 86.08 & 86.62 & 88.27 & 86.52 \\
\hline Veterinary and drugs & 8.03 & 8.65 & 7.20 & 6.51 & 7.67 \\
\hline Salt & 0.12 & 0.44 & 0.16 & 0.09 & 0.24 \\
\hline Electricity & 1.67 & 1.22 & 1.20 & 1.23 & 1.25 \\
\hline Water & 0.47 & 0.74 & 0.67 & 0.44 & 0.64 \\
\hline Insurance & - & - & 0.31 & 0.52 & 0.21 \\
\hline Artificial insemination & 4.58 & 2.54 & 3.05 & 2.55 & 2.95 \\
\hline Marketing & - & 0.15 & - & - & 0.05 \\
\hline Machine maintenance and repairs & - & 0.07 & 0.51 & 0.37 & 0.30 \\
\hline Fuel & - & 0.11 & 0.28 & 0.03 & 0.17 \\
\hline Total & 100.00 & 100.00 & 100.00 & 100.00 & 100.00 \\
\hline
\end{tabular}

Table 2 - Fixed costs per animal unit according to farm group (USD) and distribution (\%)

\begin{tabular}{|c|c|c|c|c|c|}
\hline \multirow{2}{*}{ Fixed costs element } & \multicolumn{4}{|c|}{ Farm group } & \multirow{2}{*}{ Average } \\
\hline & I & II & III & IV & \\
\hline \multicolumn{6}{|c|}{ Value (USD/animal unit) } \\
\hline Depreciation & 121.41 & 85.21 & 86.02 & 106.79 & 90.84 \\
\hline Interest & 140.59 & 84.38 & 78.69 & 102.09 & 87.57 \\
\hline Labour $^{1}$ & 844.53 & 452.63 & 264.66 & 128.29 & 342.21 \\
\hline General management expenses & 41.69 & 36.56 & 27.92 & 32.71 & 32.04 \\
\hline Total & 1148.22 & 658.78 & 457.30 & 369.88 & 552.66 \\
\hline \multicolumn{6}{|c|}{$\%$} \\
\hline Depreciation & 10.57 & 12.93 & 18.81 & 28.76 & 16.44 \\
\hline Interest & 12.24 & 12.81 & 17.20 & 27.49 & 15.85 \\
\hline Labour $^{1}$ & 73.55 & 68.71 & 57.86 & 34.55 & 61.92 \\
\hline General management expenses & 3.63 & 5.55 & 6.11 & 8.81 & 5.79 \\
\hline Total & 100.00 & 100.00 & 100.00 & 100.00 & 100.00 \\
\hline
\end{tabular}

${ }^{1}$ Family labour fee and permanent non-family worker fee. 
Table 3 - Economic indicators in farms groups

\begin{tabular}{|c|c|c|c|c|c|}
\hline \multirow{2}{*}{ Indicator } & \multicolumn{4}{|c|}{ Farm group } & \multirow{2}{*}{ Average } \\
\hline & I & II & III & IV & \\
\hline & \multicolumn{4}{|c|}{ Value (USD) } & \\
\hline Dairy products production value & 56.27 & 240.66 & 667.29 & 80.24 & 423.8 \\
\hline Productive stock value & 695.74 & 5527.98 & 5908.8 & 46794.92 & 10692.24 \\
\hline Manure value & 68.3 & 393.58 & 584.18 & 5796.61 & 1161.82 \\
\hline Variable cost per animal unit & 1391.03 & 1219.23 & 932.05 & 1091.06 & 1068.86 \\
\hline Fixed cost per animal unit & 1148.22 & 658.78 & 457.30 & 369.88 & 552.66 \\
\hline Total cost per animal unit & 2539.25 & 1878.01 & 1389.34 & 1460.94 & 1621.52 \\
\hline Variable costs & 2586.82 & 9707.41 & 17131.79 & 102723.05 & 24929.84 \\
\hline Gross margin & -222.91 & 1739.17 & 6150.88 & 51784.37 & 10266.98 \\
\hline Gross margin per animal unit & -13.80 & 188.10 & 384.62 & 644.65 & 332.65 \\
\hline Milk production (kg/year) & 2614.98 & 8665.73 & 25678.12 & 154403.10 & 35587.57 \\
\hline Milk production cost per $\mathrm{kg}$ & 0.499 & 0.399 & 0.272 & 0.233 & 0.261 \\
\hline Milk sale price per $\mathrm{kg}$ & 0.327 & 0.338 & 0.349 & 0.366 & 0.355 \\
\hline
\end{tabular}

PSV - year-end animal value and animal value waves during the year are considered, calculated when there is an increase in the value.

be calculated for the overall of farm as well as it could be calculated for production branches or the products separately on the farm. Gross margin was obtained by subtracting variable costs from gross production value of dairy cattle activities of farms.

Gross margin value per animal unit was USD 332.65 on the average of farms. When farm groups were considered, group 4 was the highest in terms of gross margin per animal unit (USD 644.65) (Table 3).

Average absolute profit value of dairy cattle activities on examined farms was USD 726.38. When absolute profits of farm groups were checked, only on group 4 farms was it positive (USD 21,134.54), while in all other groups it was negative. Of 148 farms examined, the absolute profit value of only 51 farms was positive $(34.46 \%)$. On the average of farms, absolute profit value per animal unit was negative (USD -220.24). When farm groups were considered, it was highest on group 4 farm and positive (USD 273.35) (Table 3).

On the examined farms, average gross margin value was negative only on group 1 farms and positive in all other groups. Absolute profit value was positive only on group 4 farms and negative in all other groups. According to this information, it can be concluded that group 1 farm cannot cover variable costs and fixed costs; group 2 and 3 farms can cover variable costs but not fixed costs, and group 4 farms can cover variable as well as fixed costs.
Relative profitability of farms was 0.9067 , on average (Table 3). According to this information, for every 100 USD cost in dairy cattle activities of farms, the production value they earn was almost 91 USD. This findings show that the investigated dairy cattle farms were not profitable. On group 3 and 4 farms, relative profit value was above average of farm. On group 1 and 2 farms, relative profit value was below the average. In all calculations, only group 4 farms were profitable (Table 3 ).

The cost of $1 \mathrm{~kg}$ milk was USD 0.261 , on average, on the evaluated farms. When farm groups were taken into account, $1 \mathrm{~kg}$ milk production cost was USD 0.499 on group 1 farm, USD 0.399 on group 2 farm, USD 0.272 on group 3 farm, and USD 0.233 on group 4 farm. Based on this information, it could be said that only on group 4 farm was the milk production cost lower than all the other groups. On group 1 and 2 farms, milk production cost was extensively above the average (Table 3 ).

On group 1 farm, milk yield per cow was the lowest. Feed cost per cow and other accompanying total costs were highest in this group, which in turn makes milk costs the highest.

The sale price of $1 \mathrm{~kg}$ milk on examined farms was USD 0.355. In farm groups when average kilogram costs and milk sale prices were compared, one can conclude that group 1 and 2 farms sell milk below cost value and group 3 and 4 farms sell milk above cost value. 


\section{Discussion}

The number of cattle fell down to $46 \%$ from 1980 to 2009, in Turkey (Gül et al., 2010). The situation in the investigated area was also in parallel with these data. After 2005 , cattle numbers reached up to 676,707 head with the animal husbandry support and forage crop support in 2015 (TÜİK, 2016). The number of cattle in the study area has increased by $29 \%$ compared to 2000 . The structure of the cattle breeds has also changed. Of the total cattle number, $52.7 \%$ were crossbreeds, $40.6 \%$ were pure breeds, and $6.7 \%$ were local breeds, in 2015 . The percentage of pure breeds was 12.3, and that of local breeds was 23.8 , in 2000, in the region.

On the examined farms, average gross margin was negative only on group 1 farms and positive in all other groups. Absolute profit value was positive only on group 4 farms and negative in other groups. In light of this information, it can be concluded that group 1 farms cannot cover both variable costs and fixed costs; group 2 and 3 farms can cover variable costs but not fixed costs, whereas group 4 farms can cover both variable and fixed costs. These findings could also be seen in relative profit values. For every 100 USD cost in dairy cattle activities of farms, the production value the farms earn was almost 91 USD. In other words, they were not profitable. Relative profitability of farms was 0.9067 . In all profitability indicators, only group 4 was a profitable. Gül (1998) found that milk selling constituted the highest rate of total gross production value in Adana province and average dairy farms with project gross margin and absolute profit was 2.5 and 3.36 times more than those which do not have projects. Dağıstan et al. (2009) found that scale efficiency was 0.72 in the east Mediterranean region of Turkey. They suggested that farmers should adopt new methodologies, which decrease the costs and excess input usage in order to increase efficiency.

Wieck and Heckelei (2007) aimed to expose the variation on the marginal costs on dairy farms in important production regions of the European Union. The authors determined that the results show considerable regional differences in the impact of the outputs, input prices, and fixed factors on marginal costs. Gonçalves et al. (2008) analyzed technical and scale efficiencies of milk production farms in Minas Gerais region of Brazil, considering different production levels and determined that small farmers have the potential to expand their production and productivity, since they were performing with increasing returns to scale. It was also determined that large farmers presented the best measures of technical efficiency, which was explained by factors such as access to rural credit, training, and technical support.

Semerci et al. (2014) conducted a study on 141 dairy cattle farms in Hatay province of Turkey and determined that large farms (10 head and above) obtained higher milk yield and more gross margin compared with small (1-4 head) and middle (5-9 head) scale farms.

In a similar study carried out in Adana, the GPV of farms was the combination of milk production value (79.84\%), productive stock value $(17.99 \%)$, dairy products production value (1.39\%), and manure value (0.79\%) (Y1lmaz, 2010). In another experiment carried out in Hatay, GPV of farms was the combination of milk and dairy products $(76 \%)$, productive stock value $(22 \%)$, and manure value $(2 \%)$ (Y1lmaz et al., 2000).

On dairy cattle farms, feed cost was an important part of variable costs and total production cost. This finding was also similar to studies carried out in the past. Labour costs was the second most important cost in the total costs. Only $11.49 \%$ of farms outsource the workforce permanently. Family labour was significant on the dairy cattle farms in the investigated region. Günlü et al. (2001) determined that feed cost was the item of highest (58.45\%) cost on dairy cattle farms in Afyon province. Ozawa et al. (2005) analysed efficiency and financial performances of dairy cattle farms in Hokkaido province of Japan and New Zealand and found that feed, interest rate, and payments represented more than $60 \%$ of cost elements in New Zealand. In Hokkaido, feed costs were calculated as $73 \%$ of total costs. Aktürk et al. (2010) stated that forage and concentrated feed costs were $57 \%$ of all production costs and $71 \%$ of all variable costs in Çanakkale province of Turkey. Gündüz and Dağdeviren (2011) conducted a survey with 73 producers in Bafra province of Samsun with the purpose of determining cow milk production cost and determined that feed costs were ranked 1st in total cost. Also, Keskin and Dellal (2011) found that feed cost was ranked 1 st, followed by veterinary-drugs, artificial insemination, electricity, water, and temporary labour costs, respectively, for the dairy cattle production activity in Thrace region. Semerci et al. (2014) determined that the feed cost was highest, $81.6 \%$, in the variable costs on dairy cattle farms in Hatay province.

In farm groups, when average costs and milk sale prices were compared, we observed that group 1 and 2 farms sell milk below cost value and group 3 and 4 farms sell milk above cost value. Group 1 was the highest, with $1 \mathrm{~kg}$ milk cost, while the lowest was group 4. Erkuş et al. (1996) carried out a study in Tekirdag and found out that the cost of $1 \mathrm{~kg}$ milk was lower in crossbred dairy cattle farms than imported breed cattle farms. In the study carried 
out in Czech Republic by Kopecek (2002), the author found that the profitability limit was $5,760 \mathrm{~L}$ per dairy cow.

The objectives of the livestock policies applied in Turkey are to develop animal husbandry, increase the healthy production and sustainability, protect and develop domestic animal genetic resources, keep a records system, increase the efficiency of livestock policies, and support the breeders to combat animal diseases. There have been very satisfactory support programmes for the animal in the past eight years. These policies contributed to the significant development of the animal sector of the investigated region and Turkey. The amount of support in livestock was not added to GPV. By adding support value, economic indicators can be improved a bit more. Particularly, members of agricultural organizations of small farmers were a very low rate. Producers who cover all costs of dairy farming, which requires a challenging production process, have to sell milk below cost value. For this region, it was specified that milk collectors play a significant role in the marketing of the milk produced. Intermediaries, named milk collectors, collect the milk and transport (sell) it to consumers in the streets, producers, or milk factories. This is one of the reasons why milk collectors play a significant role in marketing. Another reason is that collectors offer feed to producers in return for milk. Cooperatives were followed by milk collectors in terms of milk collecting.

\section{Conclusions}

Small-sized farms are getting lost in the dairy cattle activity due to the high cost. Cooperatives, unions, and other producer organizations do not have an effective participation in the sector in the region. To make sure that market is more functional, producers should be organized during the marketing stage. The government should take regulatory measures to improve milk marketing and make sure that the producer is more benefited. Cooperatives are usually not financially strong. Cooperatives should be financially empowered and under the protection of government.

Small-sized farms should be ensured converted into medium- and large-sized farms with low-interest loan support. This could reduce other problems encountered in animal husbandry.

\section{Acknowledgments}

This study was supported by TAGEM (Project number: TAGEM/TEAD/12/TE/000/009).

\section{References}

Aktürk, D.; Bayramoğlu, Z.; Savran, F. and Tatlidil, F. F. 2010. The factors affecting milk production cost: Çanakkale Case- Biga. Journal of the Faculty of Veterinary Medicine, Kafkas University, $16: 329-335$

Çiçek, A. and Erkan, O. 1996. Research and Sampling Methods in Agricultural Economics. Gaziosmanpaşa University, Publications of Faculty of Agriculture, No: 12, Lecture Notes Serial No: 6, Tokat, Turkey.

Dağıstan, E.; Koç, B.; Gül, M.; Parlakay, O. and Akpınar, M. G. 2009. Identifying Technical efficiency of dairy cattle management in rural areas through a non-parametric method: A case study for the East Mediterranean in Turkey. Journal of Animal and Veterinary Advances 8:863-867.

Erkuş, A.; Bülbül, M.; Kiral, T.; Açil, F. and Demirci, R. 1995. Agricultural economics. Ankara University Agricultural Faculty Publications, Ankara, Turkey (in Turkish).

Erkuş, A.; Turan, A.; Eliçin, A.; Tanrivermiş, H.; Özçelik, A. and Gündoğmuş, E. 1996. Comparative economic analysis of dairy farming which produce milk from imported and crossbred cattles in Tekirdağ Province. Turkish High Agricultural Engineers Union Publication: 14, Ankara, Turkey.

FAO - Food and Agriculture Organization of the United Nations. Yield of dairy cattle's statistics. 2016. Available at: <http://www. fao.org >. Accessed on: Mar. 1, 2016.

FAOSTAT - Food and Agriculture Organization of The United Nations Statics Division. 2016. Dairy production's statistics. Available at: $<$ http://faostat3.fao.org $>$. Accessed on: Mar. 3, 2016.

Gonçalves, R. M. L.; Vieira, W. D. C.; Lima, J. E. and Gomes, S. T. 2008. Analysis of technical efficiency of milk-producing farms in Minas Gerais. Economia Aplicada 12:321-335.

Gül, A. 1998. Economic comparison of dairy farms in Adana Province with or without a project. Çukurova University, Publications of Faculty of Agriculture, Publication No: 131, Adana, Turkey (in Turkish).

Gül, M.; Yılmaz, H.; Akpınar, M. G. and Bozkurt, Y. 2010. Recent developments in animal production sector of Turkey and future expectations. Bulgarian Journal of Animal Science 46:226-236.

Gündüz, O. and Dağdeviren, M. 2011. Determination of production cost of cow milk and functional analysis of factors affecting milk production in the Bafra District. Yüzüncü Yil University Journal of Agricultural Sciences 21:104-111 (in Turkish).

Günlü, A.; İmik, H. and Tekerli, M. 2001. General characteristic of dairy cattle farms in Afyon Province and productivity and profitability analysis. Journal of Lalahan Livestock Research Institute 41:1-12 (in Turkish).

Keskin, G. and Dellal, İ. 2011. Gross margin analysis for dairy cattle in Trakya Region. Journal of the Faculty of Veterinary Medicine, Kafkas University, 17:177-182 (in Turkish).

Kopecek, P. 2002. Analysis of the yield milk effect on the economics of milk production. Agricultural Economics-Czech 48:473-479.

Ozawa, T.; Lopez-Villalobos, N. and Blair, H. T. 2005. Dairy farming financial structures in Hokkaido, Japan and New Zealand. Animal Science Journal 76:391-400.

Semerci, A.; Parlakay, O. and Çelik, A. D. 2014. Gross margin analysis in dairy cattle: a case study of Hatay Province, Turkey. Custos e (a)gronegócio on line 10:154-170.

TÜIK - Turkish Statistics Institute. 2014. Statistical data. Available at: $<$ http://www.tuik.gov.tr>. Accessed on: Oct. 20, 2014.

TÜİK - Turkish Statistics Institute. 2016. Statistical data. Available at: $<$ http://www.tuik.gov.tr>. Accessed on: Mar. 3, 2016. 
Wieck, C. and Heckelei, T. 2007. Determinants, differentiation, and development of short-term marginal costs in dairy production: an empirical analysis for selected regions of the EU. Agricultural Economics 36:203-220.

Yılmaz, İ.; Dağistan, E.; Özel, R. and Koç, B. 2000. Economic analysis of dairy farms in Hatay Province. Research Projects. Cukurova University, Adana, Turkey.
Y1lmaz, H. 2010. Economic and social effects of support through Cooperatives to Dairy Farms: Case of Adana Province. PhD thesis. Cukurova University, Adana.

Yurdakul, O. 1978. Economic structure of dairy farms and milk marketing and consumption in Adana province. Associate professorship dissertation. Cukurova University, Adana (in Turkish). 